\title{
Discussion on regional revitalization using woody biomass resources as renewable energy
}

\author{
Yuka Nakahara ${ }^{1} \cdot$ Tomohiro Tabata $^{1} \cdot$ Tomoko Ohno $^{1} \cdot$ Fumiko Furukawa $^{1} \cdot$ Katsuro Inokuchi $^{1} \cdot$ Keiko Katagiri $^{1}$. \\ Yosuke Hirayama ${ }^{1}$
}

Received: 24 December 2018 / Accepted: 6 March 2019 / Published online: 14 March 2019

(C) The Author(s) 2019

\begin{abstract}
Expanding the use of renewable energy is a matter of concern in many countries. Many Japanese local municipalities are attempting to promote business creation using renewable energy as an opportunity for regional revitalization based on the policy of the Japanese government. Renewable energy makes significant contributions to the region in terms of energy security, stable energy supply, and job creation. However, the most important contribution is enhancing residents' attachment to their community and supporting actions that appeal to the community through renewable energy utilization. Residents should actively participate in regional revitalization, which leads to sustainable prosperity of the region. However, the current measures of local municipalities seem to be lacking such a viewpoint. This study aims to analyse the environmental and economic aspects as well as the social acceptance of establishing a bathing business that utilizes woody biomass as its heat source. This study also discussed how the generation of heat from woody biomass contributes to regional revitalization. The case study area was Kobe and Mt. Rokko, Japan. First, heat production and utilization was assumed for the forest resources in Mt. Rokko, and the annual biomass energy production potential was estimated. The annual costs of lumber cutting, transportation, and chipping, and the annual $\mathrm{CO}_{2}$ reduction by substituting bunker $\mathrm{A}$ with woody biomass for heat production were also estimated. A questionnaire survey was conducted to determine community awareness of energy production using woody biomass from Mt. Rokko. Principal component analysis, contingent valuation method, and path analysis were used to quantify respondents' awareness.
\end{abstract}

Keywords Woody biomass $\cdot$ Bathing $\cdot$ Social acceptance $\cdot$ Contingent valuation method $\cdot$ Path analysis

\section{Introduction}

The proliferation of renewable energy is an important matter for many countries. The share of renewable energy (excluding hydropower) in the world's electricity production was only $0.6 \%$ in 1973 , but has increased to $7.1 \%$ by 2015 [1]. The proportion of renewable energy in global electricity production is projected to reach $75 \%$ in 2060 . Global heat production from biomass is projected to increase from 364 million tonnes of oil equivalent (TOE) in 2013 to 864 million TOE by 2040 [1]. In Japan, the '5th Energy Basic Plan' was announced in July 2018 [2]. According to this plan, the goal is raise the proportion of renewable energy in total

Tomohiro Tabata

tabata@people.kobe-u.ac.jp

1 Kobe University, 3-11 Tsurukabuto, Nada-ku, Kobe 657-8501, Japan electric power production to $22-24 \%$ by 2030 . Before the 2011 Great East Japan Earthquake, the proportion of renewable energy in electric power production was $10 \%$. The plan also includes the goal of making renewable energy the main source of electricity. The spread of renewable energy using the feed-in tariff (FIT) scheme has been progressing in Japan since 2012, and further expansion is targeted based on the plan. In line with these goals, many local municipalities are trying to promote business creation using renewable energy as a tool for regional revitalization. The efforts of these local municipalities are motivated/driven by the 'Promotion of Overcoming Population Decline and Vitalizing Local Economy in Japan (POPDVLE)' policy adopted by the Japanese government in 2014. The POPDVLE was implemented to stop the current population decline in Japan. It offers a vision for communities in which each resident has hopes and aspirations for their community, is able to live a comfortable life, 
and is able to have a job and/or create a business utilizing the community's resources [3].

The Japanese government has carried out various regional revitalization initiatives under the POPDVLE concept. For example, it is one of the priorities of the 'Fifth Environmental Basic Plan' announced by the Japan Ministry of Environment [4] in April 2018, which aims to create an environmentally, economically, and socially sustainable region using regional resources. To this end, regional resources have been classified into environmental (forests, plants, landscapes, etc.), economic (tourism, regional brands, etc.), and social resources (attachment to the region, education, culture, etc.). Forests, which are representative of environmental regional resources, can be used to produce renewable energy through the use of woody biomass. In Japan, $66 \%$ of the national land area $\left(378,000 \mathrm{~km}^{2}\right)$ is covered by forests, with $41 \%$ of forested areas classified as artificial (plantation) forests [5]. The plantations require maintenance through regular thinning, and thinned lumber can be used as building materials and renewable energy source. Japan is a forestry country as mentioned above, and regional cities in Japan are especially forested. Using local renewable energy sources, it is possible to develop regional energy distribution systems [6, 7]. In addition to the FIT scheme, energy production from woody biomass is being actively implemented using subsidies from the national government, as part of the POPDVLE. For example, across Japan, more than 100 woody biomass power plants have been constructed and are in operation [8]. Renewable energy is a regionally distributed energy source produced locally for local consumption. The renewable energy system is supported by residents who value its benefits such as climate change mitigation, energy security, stable energy supply, job creation, and contributions towards revitalizing the regional economy [9-14]. Exploiting woody biomass that exists in the region is consistent with the philosophy of renewable energy.

Energy use of woody biomass existing in the region as a method of regional revitalization has a positive effect on the improvement of the environmental aspect on the regional and global scale. For example, the woody biomass is used as a substitute for fossil fuels, which functions to save fossil fuel resources and to mitigate the climate change. Although the artificial forests dominate most of the forest area of Japan, many of them have been planted by national policy after the World War II. It is necessary to regularly maintain the forest such as thinning of the artificial forests. However, regularly maintaining the forest has not been conducted enough due to the aging of forest managers, lack of budget, falling timber prices, etc. If adequate maintenance for the artificial forests is not conducted, the trunk is thin and carbon absorption by photosynthesis is reduced. Inadequate forest maintenance causes natural disasters like landslides during heavy rain, because the roots are not deep underground.
Utilizing renewable energy from thinned timber generated by thinning of the artificial forests not only promotes renewable energy use, but also aids in appropriate maintenance of the artificial forests.

However, electricity from woody biomass is not just consumed in the area where it is produced as electricity, but it also flows outside the region through the national power grid. Electricity produced by thermal power, nuclear power, photovoltaic power, etc., is all combined in the national power grid. However, electricity produced from woody biomass cannot be distinguished, making it difficult for residents to perceive the benefits of locally produced electricity as an energy source. Kollmann et al. [15] indicated that the distance in which heat can be transported is limited owing to heat loss in the supply networks, even if heat from woody biomass was produced and supplied in the form of warm water, or for cooling/heating. However, the produced heat can be used in facilities near the heat production site; in such cases, residents might perceive the benefits of energy produced from woody biomass. While the contribution of woody biomass to regional revitalization is important, the essence of the revitalization is not simply the reduction of the local environmental burden or job creation using regional resources, but also the enrichment of region and residents' minds. This means enhancing residents' attachment to their community and supporting actions that appeal to the community. Šahovića and Silva [16] indicated that the benefits of a community renewable energy project are widespread, including local job creation, local infrastructure regeneration, provision of local education resources, and raising the local population's awareness of the issue of sustainable energy.

Currently, regional revitalization measures in Japan have been implemented with the aid of subsidies, and many local municipalities have given priority to established types of industrial projects. The enrichment of the region and residents' minds has not been fully adopted because of the difficulty of visualizing their benefits. In addition, many local municipalities have looked at the large-scale application of woody biomass for electricity production, but investigations about heat production and its use as an alternative energy source have been insufficient. In particular, regional cities with plentiful forests tend to have a low population density, which could increase investment costs, thus reducing the cost effectiveness to the community if the energy usage density is low $[17,18]$. Therefore, it is necessary to consider creating a business that can generate sufficient supply despite the small energy demand. Residents should actively participate in regional revitalization, which leads to sustainable prosperity of the region. Residents who live in the region or community are key players in the POPDVLE. Evaluating and examining the degree of awareness that residents have regarding the production of regional resources, business 
creation, and exploitation of available regional resources are fundamental requirements for promoting the POPDVLE. However, the current measures of local municipalities seem to lack such a viewpoint.

This study examines the environmental and economic aspects, and social acceptance, of establishing a bathing business that utilizes woody biomass for heat production, as a means of contributing to regional revitalization. A case study was conducted in Kobe, Japan, in which $\mathrm{CO}_{2}$ emission reduction is treated as the environmental benefit, while the cost of procuring wood chips is used as part of the economic evaluation. Mt. Rokko, located in Kobe, is not only a place of relaxation for Kobe residents but also a place that produces forest resources. Utilizing forest resources is one of effective methods for the revitalization of Kobe. Social acceptance was measured through a questionnaire survey to document respondents' awareness regarding the creation of a bathing business and its utilization. The results of the survey were analysed using principal component analysis (PCA), contingent valuation method (CVM), and path analysis. The currency used in the study was the Japanese yen (JPY), with US dollars (USD) written in parenthesis. The exchange rate applied was 0.0090 USD $=1$ JPY (as of July 2, 2018).

Several papers have reviewed the installation of regional or community renewable energy systems. These include studies on potential renewable energy installations using geographic information systems [19, 20]; environmental impact reduction by installing renewable energy systems in households; the use of life cycle assessment and other methods [21,22]; the social acceptance of renewable energy [23-25]; residents' acceptance of converting the energy system in their homes and their choice of energy system [26-28]; and the cooperation of residents, investment options, etc., relating to the adoption of renewable energy in a community [16]. Few studies, however, have investigated the impact of creating a business that utilizes woody biomass, at the regional scale and/or community level, from environmental, economic, and social perspectives.

\section{Materials and methods}

\section{Case study area}

Figure 1 shows the target area of this study, Kobe, Japan, which has a total land area of $557 \mathrm{~km}^{2}$ and an estimated population of 1.54 million (2015). Kobe is part of the Greater Osaka region, the second largest metropolitan region in Japan. The latitude and longitude of Kobe are $34^{\circ} 41^{\prime} 0^{\prime} \mathrm{N}$ and $135^{\circ} 10^{\prime} 0^{\prime} \mathrm{E}$, respectively; the average outside air temperature was $17.3^{\circ} \mathrm{C}$ in 2015 , with a maximum of $36.0{ }^{\circ} \mathrm{C}$, and a minimum of $-0.9^{\circ} \mathrm{C}$. Approximately, $26.6 \%$ of the population is over 65 years of age, which is

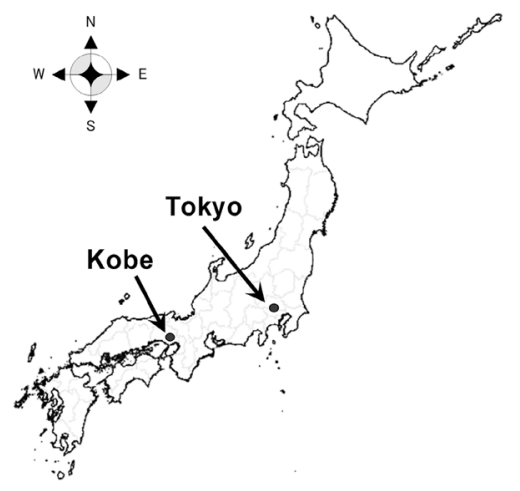

Fig. 1 Location of Kobe

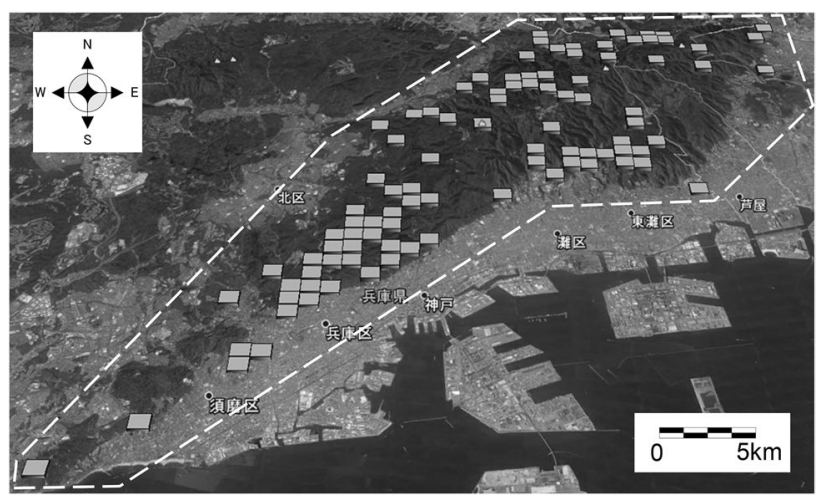

Fig. 2 Mt. Rokko and spatial distribution of woody biomass. Note that Mt. Rokko is the area enclosed by the white dotted line, and the small filled rectangles $\left(1 \mathrm{~km}^{2}\right.$ each in area) indicate locations of plantation coupes

slightly higher than the national figure $(26.0 \%)$ [29, 30]. According to the National Institute of Population and Social Security Research [31], the population decline in Kobe started in 2015, and the proportion of the population aged 65 and over is expected to reach $29.9 \%$ in 2020 and $32.7 \%$ in 2030 , rates that are considered remarkably high compared with other large cities.

Figure 2 shows the location of Mt. Rokko, which is the generic name of a mountain range stretching $30 \mathrm{~km}$ from east to west. The Kobe coastal urban area is close to Mt. Rokko, which forms an indispensable aspect of the Kobe landscape, to the point that nearly $90 \%$ of Kobe residents are very fond of or very attached to Mt. Rokko [32]. Mt. Rokko is also famous for sightseeing, and there are recreational facilities such as an observation deck, botanical garden, ski resort, athletic facilities, etc., at the top of the mountain. Approximately, 1.94 million tourists visit the mountain annually for hiking and climbing, and to generally enjoy the facilities [33]. Tourism in Mt. Rokko generates approximately JPY 27 billion (USD 244 million) annually. 
Figure 2 indicates the spatial distribution of plantation vegetation. According to spatial information on land use [34] and vegetation [35], the vegetation in Mt. Rokko covers an area of $13.4 \mathrm{~km}^{2}$. In 2014, the city government of Kobe [32] adopted a plan known as the 'Strategy for Mt. Rokko's forest management' to enhance the attractiveness of Mt. Rokko as a tourist destination; the effective use of Mt Rokko's forestry resources as woody biomass is an important part of the plan. Currently, the use of thinned lumber is practised at a small scale, although Kobe plans to develop products and energy from thinned lumber.

Unfortunately, forest maintenance of Mt. Rokko has not been sufficiently implemented, because of shortage in personnel and funding, and the devastation of the forest continues to progress. To improve this situation, the city government of Kobe [32] formulated the 'Strategy for Mt. Rokko's forest management' in 2012. The main measures in this strategy which aims to implement forest management practices are the following: launching funds for forest management, job creation for forest maintenance to develop human resources and create local jobs for forest management, partnership with citizens and local communities to promote fascinating forest creation by forest maintenance through residents' participation, environment and resources utilization considering utilization of forest resources as renewable energy and developing high-added value products and branding of forest resources. Moreover, the realisation of the regional revitalisation in Kobe by utilizing the forest and plant resources of Mt. Rokko is also intended. Figure 3 shows a concept schematic of forest management and regional revitalisation. Forest management not only improves forest conditions but also affects the attachment of residents by improving landscapes. Additionally, it also affects the growth of regional industries and creates jobs through the utilization of forest resources. Thus, implementing forest management practices should be profitable for the mountain, the residents and for local industries.

\section{Energy utilization potential and environmental and economic perspectives}

First, we study the potential energy production and its environmental and economic effects to confirm whether energy utilization of the woody biomass at Mt. Rokko is worth considering as a method of regional revitalization. We estimated the thinning area at Mt. Rokko based on the spatial distribution of plantation vegetation, as shown in the grid in Fig. 2; the annual lumber availability and associated potential energy production are presented in Table 1 . We assumed that each grid of the thinning area is divided into 20 sections to avoid clear cuts, and each section was thinned annually based on Tabata et al. [36]. In other words, the annual lumber production potential was estimated by dividing the thinning area into 20 .

If forest roads are not available, transporting heavy machinery to the thinning sites and then transporting thinned lumber to the end use site (bathing facilities) is an important issue that should be considered in relation to the project energy budget and economics. In this study, the annual energy utilization potential was estimated by taking the forest road network into consideration; hence, thinning was assumed to occur in the grid at locations identified using spatial information, where the vegetation area and road grid overlap [34, 35], and by setting the maximum distance at which machinery can enter the forest from the forest access roads as $200 \mathrm{~m}$ [37].

The cost intensity consists of the expenses incurred from thinning, transportation, and chipping processes. After calculating the annual energy utilization potential, the overall cost was identified by multiplying the annual energy utilization potential by the cost intensity, as shown in Table 1 . The selected $\mathrm{CO}_{2}$ intensity is the amount released when bunker A or light oil is used for energy or heat production, and the $\mathrm{CO}_{2}$ reduction effect was also identified by multiplying the annual energy utilization potential and the selected $\mathrm{CO}_{2}$ intensity. The reason for applying the data for bunker $\mathrm{A}$ and
Fig. 3 Conceptual diagram of forest management and regional revitalisation in Kobe. This figure was created for the case of the renewable utilization of forest (energy) resources

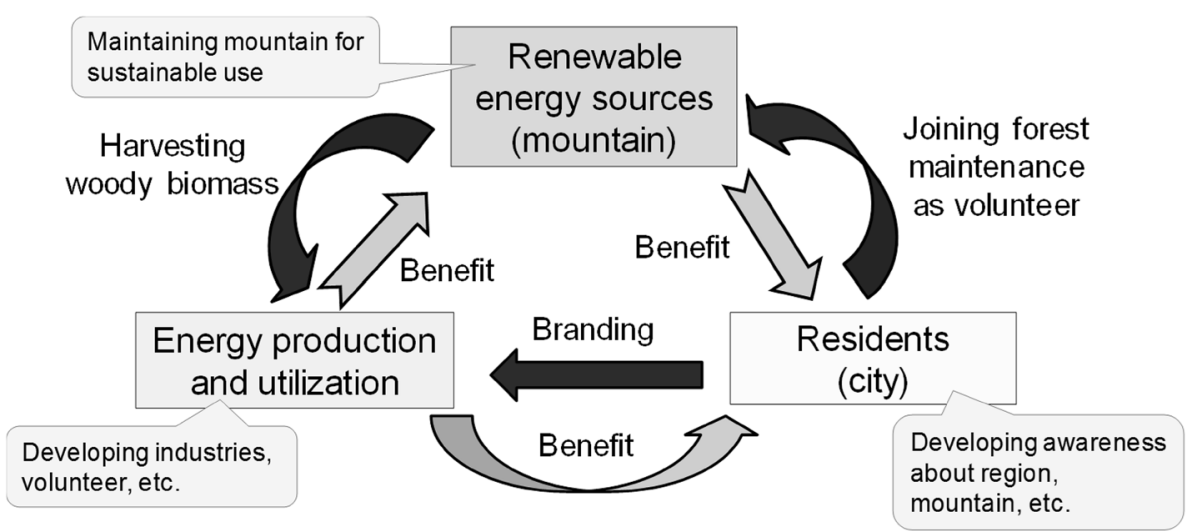


Table 1 Environmental and economic data

\begin{tabular}{lll}
\hline Annual production of lumber & 3500 & $\mathrm{~m}^{3} / \mathrm{km}^{2}$ \\
Specific gravity of lumber & 0.91 & $\mathrm{t} / \mathrm{m}^{3}$ \\
Lower heating value of chip & 19,000 & $\mathrm{MJ} / \mathrm{t}$ \\
$\mathrm{CO}_{2}$ intensity for electricity production & 137.78 & $\mathrm{~kg}-\mathrm{CO}_{2} / \mathrm{GJ}$ \\
$\mathrm{CO}_{2}$ intensity for heat production using bunker A & 69.30 & $\mathrm{~kg}-\mathrm{CO}_{2} / \mathrm{GJ}$ \\
$\mathrm{CO}_{2}$ intensity for heat production using light oil & 67.83 & $\mathrm{~kg}-\mathrm{CO}_{2} / \mathrm{GJ}$ \\
Cost intensity & & \\
Thinning & $604 \mathrm{JPY}$ (5.5 USD) & $/ \mathrm{t}$ \\
Transportation & $957 \mathrm{JPY}$ (8.6 USD) & $/ \mathrm{t}$ \\
Chipping & $140 \mathrm{JPY}(1.3 \mathrm{USD})$ & $/ \mathrm{t}$ \\
Total & $1702 \mathrm{JPY}(15.4 \mathrm{USD})$ & $/ \mathrm{t}$ \\
\hline
\end{tabular}

Note: [34, 36-38] light oil in Table 1 is that these fuels are used as boiler fuel for bathing facilities in Japan.

\section{Questionnaire survey}

To begin the study, we conducted a survey in the form of an online questionnaire to determine residents' awareness regarding the utilization of woody biomass from Mt. Rokko to produce energy. The respondents were 522 Kobe residents who were registered with a survey firm, and the survey was conducted on the 12th and 13th of December 2017. The number of respondents in each age group was set so as to correlate with the population composition of Kobe. Ethical clearance and approval for the survey and questionnaire contents were given by the Graduate School of Human Development and Environment, Kobe University.

The questions were related to the respondents' demographics (Table 2) and were divided into two main groups: first, relating to the level of awareness in six categories [environment, region, myself, disaster prevention, forest,
Mt. Rokko (Table 3)]; and second, relating to the likelihood of using a bathing facility that utilizes heat produced with thinned lumber from Mt. Rokko (Table 4). Before presenting questions to respondents, the concept for forest conservation and renewable energy use in 'Strategy for Mt. Rokko's forest management' was explained. The questions assumed a scenario in which a hypothetical new bathing facility for residents was constructed at the foot of Mt. Rokko. It was explained in the questionnaire that the wood was to be burned in a boiler to produce heat, which will then be used to heat the water supplied to the baths. Many bathing facilities in Japan use woody biomass or other combustibles instead of fossil fuel $[8,17]$. In Table 4, the proposed usage fee for the hypothetical Mt Rokko baths was set at 800 JPY (7.2 USD). In the questionnaire, we included questions about how much respondents are willing to pay/contribute, aside from the usage fee, for the maintenance of Mt. Rokko forests. In this case, we initially asked if the respondents would be prepared to pay 200 JPY (1.8 USD). If respondent answered 'Yes', then the proposed contribution was raised to $300 \mathrm{JPY}$ (2.7

Table 2 Questions regarding demographics

\begin{tabular}{|c|c|}
\hline Questions & Choice \\
\hline Sex & 1: Male and 2: female \\
\hline Age & $\begin{array}{l}\text { 1: } 20-24 \text { years, } 2: 25-29 \text { years, } 3: 30-34 \text { years, } 4: 35-39 \text { years, } 5: 40-44 \text { years, } 6: 45-49 \text { years, } 7: \\
50-54 \text { years, } 8: 55-59 \text { years and } 9: 60 \text { years and over }\end{array}$ \\
\hline Married or unmarried & 1: Unmarried and 2: married \\
\hline Presence of children & 1: No and 2: yes \\
\hline $\begin{array}{l}\text { Household annual income } \\
\text { [thousand JPY] } \\
(1 \text { USD }=0.0090 \text { JPY })\end{array}$ & $\begin{array}{l}\text { 1: Less than 2000, 2: 2000-3999, 3: 4000-5999, 4: 6000-7999, 5: 8000-9999, 6: 10,000-11,999, 7: } \\
\text { 12,000-14,999, 8: 15,000-19,999, 9: Over 20,000 and no answer }\end{array}$ \\
\hline Job & $\begin{array}{l}\text { 1: Civil servant, 2: manager/officer, 3: employee, 4: self-employed/free work, 5: part-time job, 6: no occu- } \\
\text { pation/housewife (husband), 7: student and 8: other }\end{array}$ \\
\hline Type of housing & 1: Detached housing, 2: complex housing and 3: other type \\
\hline Residence years & 1: Less than 1 year, $2: 1-5$ years, $3: 6-10$ years, $4: 11-20$ years, $5: 21-30$ years and $6:$ over 31 years \\
\hline Frequency of visit to Mt. Rokko & 1: Everyday, 2: few times a week, 3: few times a month, 4 : few times a year and 5: never visited \\
\hline Reason for visiting to Mt. Rokko & 1: Work, 2: leisure, 3: volunteer activities, 4: education and 5: other reason \\
\hline
\end{tabular}


Table 3 Questions regarding respondents' awareness

\begin{tabular}{|c|c|}
\hline (1) Environment & $\begin{array}{l}\text { It is important to choose environmentally friendly products and services } \\
\text { It is important that people should cooperate to tackle the regional environmental conservation activities. Because these } \\
\text { activities lead to the revitalization of region } \\
\text { Public involvement is important if local municipality was considering environmental conservation measures } \\
\text { Individual actions in daily life greatly affect the environment } \\
\text { Advancing environmental conservation efforts will lead to economic development }\end{array}$ \\
\hline (2) Region & $\begin{array}{l}\text { I want to find the richness of my life by doing something with everyone in the region } \\
\text { I want to actively participate in local activities (festivals, events, etc.) } \\
\text { To improve the living environment of the area, I want to cooperate as much as I can if I can do it } \\
\text { I feel pride and affection for the natural and scenery of the area where I live in } \\
\text { I want to continue living in the region where I live in the future }\end{array}$ \\
\hline (3) Myself & $\begin{array}{l}\text { I am satisfied with my life } \\
\text { My household status is good } \\
\text { My health condition is good } \\
\text { When I am in trouble, I rely on my neighbourhood } \\
\text { I have a lot of personal relationships around my neighbourhood }\end{array}$ \\
\hline (4) Disaster prevention & $\begin{array}{l}\text { When a natural disaster occurs, I depend on my family, acquaintance, self-governing body and neighbourhood associa- } \\
\text { tion } \\
\text { When a natural disaster occurs, I rely on local municipality and volunteer } \\
\text { I know the evacuation route to evacuation center in the event of a disaster } \\
\text { Growing and maintaining forest are important for restraining and mitigating sediment-related disasters } \\
\text { When a natural disaster occurs, I am the only one to rely on }\end{array}$ \\
\hline (5) Forest & $\begin{array}{l}\text { I am interested in conservation and effective utilization of local forest } \\
\text { Regional forests are in a serious situation } \\
\text { Regional forest preservation activities by residents' groups are effective for local forest conservation } \\
\text { I am responsible for local forest degradation } \\
\text { Participating in regional forest preservation activities through volunteering and event planning is laborious, time con- } \\
\text { suming and cumbersome }\end{array}$ \\
\hline (6) Mt. Rokko & $\begin{array}{l}\text { Forest and plants of Mt. Rokko can contribute to regional revitalization } \\
\text { It is important to utilize the forest resources and plants of Mt. Rokko as the Mt. Rokko brand } \\
\text { Training human resources who are responsible for growing and maintaining the forest and plants of Mt. Rokko is } \\
\text { important } \\
\text { Mt. Rokko is rich in nature } \\
\text { Cost for conserving and training of forest and plants of Mt. Rokko should be borne by the local residents }\end{array}$ \\
\hline
\end{tabular}

Answer. 1: I think so, 2: I agree a little, 3: I cannot say either, 4: I do not think so and 5: I do not think so at all

Table 4 Questions regarding contributions
(1)

(2)
Imagine that a day-trip bathing facility equipped with facilities to warm water using the woody biomass harvested at Mt. Rokko will be built at the foot of Mt. Rokko. The usage fee of this bathing facility is 800 JPY per adult. In this bathing facility, the contributions to support the growing and maintaining of the forest of Mt. Rokko is added to the usual usage fee '200 JPY per adult'. At this time, do you consider paying the contributions in addition to the use fee for bathing facility? Answer. 1: Yes* and 2: No**
*If answer was 'Yes', the same question was asked again with a charge of 300 JPY Answer. 1: Yes and 2: No
**If answer was 'No', the same question was asked again with a charge of $100 \mathrm{JPY}$ Answer. 1: Yes and 2: No

USD), and the question was asked again. If the respondent answered 'No', then the proposed contribution was reduced to $100 \mathrm{JPY}$ (0.9 USD), and the question was asked again.

The reason for selecting a bathing facility in this study is that the annual energy production potential for lumber is not large (as shown in Sect. 3.1), and using it to produce heat would make a greater contribution to residents than electricity production. Another reason is that the Japanese have a culture of taking a bath or shower every day [41]. The Japanese bathroom, known as 'Furo', is not only installed in most Japanese houses but also in public bathing facilities, hostels, hotels, dormitories, etc. [42]. For example, there are approximately 25,000 public bathing facilities in Japan, and approximately 270 million visitors use them as part of their leisure activities [43, 44]. Walker [45] determined the scope of tourism as travel, lodging, food service, and recreation. 
For the Japanese, the use of bathing facilities is as familiar an activity as tourism. Considering the above, the authors considered it to be realistic, in the survey context, to propose the use of woody biomass for the bathing facility in this study.

The results obtained from the survey were converted from qualitative variables into numerical variables to conduct statistical analysis. The conversion method applied was as follows: for the choices made in response to the questions in Tables 2, 3, and 4, the numbers seen before the options were used to replace the words. For example, in Table 3, 'I think so' is denoted as 1, 'I agree a little' as 2, and 'I cannot say either' as 3. In Table 4, 'Yes' is 1 and 'No' is 2. After the conversion, statistical analyses including PCA, CVM, and path analysis were conducted, as explained in the following subsections.

\section{PCA}

PCA reduces the dimensionality of a multivariate dataset and aids in its interpretation by identifying a smaller number of variables to represent the larger dataset [46]. For example, PCA synthesizes variables using weighting coefficients, as shown in Eq. (1), for a situation with $n$ variables.

$z_{m}=a_{m 1} x_{1}+a_{m 2} x_{2}+a_{m 3} x_{3}+\cdots+a_{m n} x_{n}$

where $z$ is the main component, $a$ is a weighting coefficient, $x$ is a variable, $m$ is the number of main components $(1 \sim m)$, and $n$ is the number of variables $(1 \sim n)$.

PCA calculates characteristic roots for a correlation matrix between variables. Then, the characteristic vector corresponding to the maximum characteristic root becomes the first principal component. Consequently, the order from the second principal component to the $m$ th principal component occurs in accordance with the magnitude of the associated characteristic root, in a cascade that ceases once the characteristic root falls below 1 . The identified principal components are named to enable interpretation of the characteristics of the principal components based on the magnitude of the weighting coefficient of each variable. PCA summarizes information by synthesizing variables. In this study, the synthesized variables are the classifications described in Table 3 relating to respondents' awareness. PCA was undertaken with the Japanese statistical software 'Bell Curve for Excel.'

\section{CVM}

CVM estimates economic values by asking people about their willingness to pay (WTP) for specific environmental services, based on a hypothetical scenario [47]. CVM was used to quantify ecological services and biodiversity loss as hypothetical monetary units. In this study, the respondents' intention to use the bathing facility and their awareness of the need for forest maintenance on Mt. Rokko were quantified using CVM. CVM was applied to quantify the WTP-related answers to questions regarding contributions (Table 4) using dichotomous choice CVM in a double-bound formulation. A distribution function that expresses the 'pros and cons' of the presented options can be described using the logic model shown in Eq. (2) [48].

$G(T)=\frac{1}{1+\exp \left(\beta_{0}+\beta_{T} \ln T+\sum \beta_{k} x_{k}\right)}$

where $T$ is the bid value, $\beta$ is the estimated parameter, $x$ is the explanatory variable vector, $k$ is the number of elements $(1 \sim k)$, and $O$ is a bid value of $0 \mathrm{JPY}$.

A multivariate analysis was conducted to analyse the demographics of respondents' answers (Table 2), and the synthesized variables obtained by PCA (Table 3) that affected the WTP. The multivariate analysis summarized the WTP by the conceptual model shown in Eqs. (3) and (4) [47].

$W T P=f\left(T, a_{1}, a_{2}, a_{3}, \ldots, a_{i}\right)$

where $a$ represents factors $(1 \sim i)$ that affect the WTP.

Equation (3) can be expanded into Eq. (4) using the log-linear model.

$\ln \left(\frac{P(\text { yes })}{1-P(\text { yes })}\right)=b_{0}-b_{1} T+b_{1} a_{1}+b_{2} a_{2}+b_{3} a_{3}+\cdots+b_{i} a_{i}$

where $P($ yes $)$ is the probability that the answer will be 'Yes' against the bid value, and $b$ is the coefficient $(1 \sim i)$.

We conducted CVM using the Japanese CVM analysis software 'Excel for CVM Version 4.0' [48].

\section{Path analysis}

The structural equation modelling (SEM) is the most important method used to establish an appropriate model for evaluating a series of simultaneous hypotheses about the impact of latent and manifest variables on other variables; it also includes the ability to take measurement errors into account [49]. Path analysis is an analysis model that applies multiple linear regression analysis and SEM. Path analysis visualizes the correlation between variables using regression analysis. In this study, we clarified degree of awareness of respondents who supported large forestry maintenance contributions (Table 4). For the purpose of conducting path analysis, respondents' answers regarding contributions were classified as shown in Table 5. We conducted path analysis using the statistical software package 'IBM SPSS Amos 23'. 
Table 5 Classification of answers regarding contributions

\begin{tabular}{|c|c|c|c|}
\hline \multirow{2}{*}{$\begin{array}{l}\text { Acceptable contribu- } \\
\text { tion amount }\end{array}$} & \multicolumn{3}{|c|}{ Answer of contributions } \\
\hline & $\begin{array}{l}\text { (1) } 200 \text { JPY } \\
\text { (1.8 USD) }\end{array}$ & $\begin{array}{l}\text { (2) } 300 \text { JPY } \\
\text { (2.7 USD) }\end{array}$ & $\begin{array}{l}\text { (3) } 100 \\
\text { JPY (0.9 } \\
\text { USD) }\end{array}$ \\
\hline 300 JPY (2.7 USD) & Yes & Yes & - \\
\hline 200 JPY (1.8 USD) & Yes & No & - \\
\hline 100 JPY (0.9 USD) & No & - & Yes \\
\hline $0 \mathrm{JPY}$ (0 USD) & No & - & No \\
\hline
\end{tabular}

\section{Results and discussion}

\section{Environmental and economic results}

The annual lumber production potential and energy utilization potential were estimated as $2130 \mathrm{t}$ and 40,500 GJ, respectively, based on the spatial distribution of the plantation illustrated in Fig. 2. The annual cost of thinning, transporting, and chipping the lumber was estimated as
$3,630,000$ JPY (32,800 USD). The annual $\mathrm{CO}_{2}$ reduction by substituting fossil fuels with renewable timber, if used for electricity production, was 2,230 $\mathrm{t}-\mathrm{CO}_{2}$; and if used as a substitute for bunker $\mathrm{A}$ or light oil for heat production, the reduction was $2,530 \mathrm{t}-\mathrm{CO}_{2}$ or $2,450 \mathrm{t}-\mathrm{CO}_{2}$, respectively. Although the estimated value is not large, the amount of potential energy involved indicates that there is an effective use for the energy produced in the Mt. Rokko area as heat, which is a meaningful use in terms of building renewable energy system capacity for the local region around Mt. Rokko.

\section{Questionnaire survey results}

Tables 6, 7, and 8 summarize the survey results. As the result of demographics, the gender ratios and age group sizes were determined based on the population composition of Kobe. Most respondents were aged 60 or over, married, and living in the presence of children. Many respondents lived in housing complexes and had been there for 11 years or more.

Looking at the answers relating to frequency of visits to Mt. Rokko, 'Never visit' was the dominant group,

Table 6 Respondent responses by demographic

\begin{tabular}{|c|c|c|c|c|c|}
\hline \multirow[t]{2}{*}{ Sex } & Male & $46.4 \%$ & Job & Civil servant & $33.0 \%$ \\
\hline & Female & $53.6 \%$ & & Manager/officer & $21.0 \%$ \\
\hline \multirow[t]{9}{*}{ Age } & $20-24$ years & $5.0 \%$ & & Employee & $31.2 \%$ \\
\hline & $25-29$ years & $8.6 \%$ & & Self-employed/free work & $6.7 \%$ \\
\hline & $30-34$ years & $8.0 \%$ & & Part-time job & $14.9 \%$ \\
\hline & $35-39$ years & $9.2 \%$ & & No occupation/housewife (husband) & $34.9 \%$ \\
\hline & $40-44$ years & $8.4 \%$ & & Student & $4.2 \%$ \\
\hline & $45-49$ years & $7.9 \%$ & & Other & $2.7 \%$ \\
\hline & $50-54$ years & $8.6 \%$ & Type of housing & Detached housing & $40.4 \%$ \\
\hline & $55-59$ years & $6.7 \%$ & & Complex housing & $57.9 \%$ \\
\hline & 60 years and over & $37.5 \%$ & & Other type & $1.7 \%$ \\
\hline \multirow{10}{*}{$\begin{array}{l}\text { Household annual } \\
\text { income [thousand } \\
\text { JPY] } \\
(1 \mathrm{USD}=0.0090 \mathrm{JPY})\end{array}$} & Less than 2000 & $7.1 \%$ & Residence years & Less than 1 year & $6.1 \%$ \\
\hline & 2000-3999 & $23.0 \%$ & & $1-5$ years & $17.8 \%$ \\
\hline & $4000-5999$ & $19.3 \%$ & & $6-10$ years & $13.4 \%$ \\
\hline & $6000-7999$ & $12.6 \%$ & & $11-20$ years & $26.2 \%$ \\
\hline & 8000-9999 & $8.0 \%$ & & $21-30$ years & $21.3 \%$ \\
\hline & $10,000-11,999$ & $3.3 \%$ & & Over 31 years & $15.1 \%$ \\
\hline & $12,000-14,999$ & $1.3 \%$ & Frequency of visit to Mt. Rokko & Everyday & $0.4 \%$ \\
\hline & $15,000-19,999$ & $0.8 \%$ & & Few times a week & $1.1 \%$ \\
\hline & Over 20,000 & $0.6 \%$ & & Few times a month & $3.3 \%$ \\
\hline & No answer & $23.9 \%$ & & Few times a year & $40.2 \%$ \\
\hline \multirow[t]{2}{*}{ Married or unmarried } & Unmarried & $37.0 \%$ & & Never visited & $55.0 \%$ \\
\hline & Married & $63.0 \%$ & Reason for visiting Mt. Rokko & Work & $2.1 \%$ \\
\hline \multirow[t]{4}{*}{ Presence of children } & No & $38.7 \%$ & & Leisure & $91.9 \%$ \\
\hline & Yes & $61.3 \%$ & & Volunteer activities & $0.9 \%$ \\
\hline & & & & Education & $0.4 \%$ \\
\hline & & & & Other reasons & $4.7 \%$ \\
\hline
\end{tabular}


Table 7 Respondent awareness

\begin{tabular}{|c|c|c|c|c|c|c|}
\hline & & I think so $(\%)$ & $\begin{array}{l}\text { I agree a } \\
\text { little (\%) }\end{array}$ & $\begin{array}{l}\text { I cannot say } \\
\text { either }(\%)\end{array}$ & $\begin{array}{l}\text { I do not } \\
\text { think so (\%) }\end{array}$ & $\begin{array}{l}\text { I do not } \\
\text { think so at } \\
\text { all }(\%)\end{array}$ \\
\hline \multirow[t]{5}{*}{ (1) Environment } & (i) & 17.2 & 49.0 & 27.6 & 4.4 & 1.7 \\
\hline & (ii) & 32.6 & 50.4 & 13.0 & 2.7 & 1.3 \\
\hline & (iii) & 22.4 & 51.7 & 21.1 & 3.1 & 1.7 \\
\hline & (iv) & 21.3 & 52.7 & 21.5 & 3.1 & 1.5 \\
\hline & (v) & 22.4 & 49.0 & 22.2 & 4.6 & 1.7 \\
\hline \multirow[t]{5}{*}{ (2) Region } & (i) & 9.6 & 29.9 & 36.0 & 17.8 & 6.7 \\
\hline & (ii) & 12.3 & 50.6 & 26.4 & 7.5 & 3.3 \\
\hline & (iii) & 9.6 & 35.8 & 34.9 & 14.2 & 5.6 \\
\hline & (iv) & 23.2 & 37.7 & 25.7 & 9.8 & 3.6 \\
\hline & (v) & 36.6 & 34.9 & 20.3 & 5.4 & 2.9 \\
\hline \multirow[t]{5}{*}{ (3) Myself } & (i) & 14.4 & 41.4 & 26.1 & 14.2 & 4.0 \\
\hline & (ii) & 16.3 & 46.0 & 19.5 & 12.5 & 5.7 \\
\hline & (iii) & 8.4 & 29.3 & 31.2 & 19.9 & 11.1 \\
\hline & (iv) & 13.2 & 37.2 & 25.5 & 17.0 & 7.1 \\
\hline & (v) & 4.0 & 15.7 & 26.4 & 30.5 & 23.4 \\
\hline \multirow[t]{5}{*}{ (4) Disaster prevention } & (i) & 14.4 & 36.8 & 23.2 & 17.4 & 8.2 \\
\hline & (ii) & 10.5 & 37.2 & 32.8 & 15.1 & 4.4 \\
\hline & (iii) & 15.3 & 43.7 & 26.8 & 10.2 & 4.0 \\
\hline & (iv) & 12.6 & 27.6 & 35.2 & 17.2 & 7.3 \\
\hline & (v) & 35.2 & 45.4 & 15.1 & 3.1 & 1.1 \\
\hline \multirow[t]{5}{*}{ (5) Forest } & (i) & 14.2 & 37.5 & 31.0 & 11.9 & 5.4 \\
\hline & (ii) & 12.8 & 29.5 & 37.4 & 18.0 & 2.3 \\
\hline & (iii) & 4.6 & 22.0 & 43.9 & 22.8 & 6.7 \\
\hline & (iv) & 12.5 & 44.8 & 33.3 & 7.1 & 2.3 \\
\hline & (v) & 11.3 & 34.5 & 41.8 & 10.5 & 1.9 \\
\hline \multirow[t]{5}{*}{ (6) Mt. Rokko } & (i) & 37.0 & 48.9 & 10.3 & 2.9 & 1.0 \\
\hline & (ii) & 24.1 & 47.9 & 23.6 & 3.1 & 1.3 \\
\hline & (iii) & 8.0 & 23.9 & 47.3 & 14.8 & 5.9 \\
\hline & (iv) & 22.4 & 52.5 & 21.1 & 1.9 & 2.1 \\
\hline & (v) & 27.4 & 45.4 & 22.2 & 3.6 & 1.3 \\
\hline
\end{tabular}

Table 8 Answers regarding contributions

\begin{tabular}{lllll}
\hline (1) 200 JPY (1.8 USD) & Yes & & No & \\
& $63.6 \%$ & & $36.4 \%$ & \\
(2) 300 JPY (2.7 USD) & Yes & No & & \\
& $57.2 \%$ & $42.8 \%$ & & \\
(3) 100 JPY (0.9 USD) & & & Yes & No \\
& & & $42.6 \%$ & $57.4 \%$ \\
\hline
\end{tabular}

while $40.2 \%$ of respondents visited a few times a year. With regard to the purpose of visiting, $91.9 \%$ of respondents said that their visit was for leisure. For respondents who answered that they visited Mt. Rokko a few times a year, cross-tabulation was conducted with demographics, which revealed that $37.6 \%$ of respondents in this group were over $60,69.0 \%$ were married, and $64.8 \%$ answered had children. These results imply that elderly people and respondents who are married with children tend to visit Mt. Rokko for leisure.

Table 9 shows the results of the first and second main component analysis of respondents' awareness, which were obtained by applying PCA to the answers shown in Table 7. In this paper, the principal components for each category were calculated by applying five questions as variables for each category using formula (1). The results show that only the first main component occurred in all five categories (Environment, Region, Myself, Forest, and Mt. Rokko), and these were named as 'Interest in environment', 'Interest in region', 'Interest in myself', 'Interest in forest', and 'Interest in Mt. Rokko', respectively. One category, disaster prevention, exhibited the first and second main components, which were named as 'Disaster prevention through public and mutual assistances' and 'Disaster prevention through self-assistance'. In this pair, the former component indicates that respondents consider it appropriate to conduct disaster 
Table 9 First and second main component for respondents' awareness

\begin{tabular}{|c|c|c|c|c|c|}
\hline Category & & $\begin{array}{l}\text { First main component } \\
\text { loading vector }\end{array}$ & First main component & $\begin{array}{l}\text { Second main compo- } \\
\text { nent loading vector }\end{array}$ & Second main component \\
\hline \multirow[t]{5}{*}{ (1) Environment } & (i) & 0.84 & \multirow[t]{5}{*}{ Interest in environment } & \multirow[t]{5}{*}{-} & \multirow[t]{5}{*}{-} \\
\hline & (ii) & 0.84 & & & \\
\hline & (iii) & 0.81 & & & \\
\hline & (iv) & 0.80 & & & \\
\hline & (v) & 0.77 & & & \\
\hline \multirow[t]{5}{*}{ (2) Region } & (i) & 0.83 & \multirow[t]{5}{*}{ Interest in region } & \multirow[t]{5}{*}{-} & \multirow[t]{5}{*}{-} \\
\hline & (ii) & 0.80 & & & \\
\hline & (iii) & 0.80 & & & \\
\hline & (iv) & 0.77 & & & \\
\hline & (v) & 0.59 & & & \\
\hline \multirow[t]{5}{*}{ (3) Myself } & (i) & 0.79 & \multirow[t]{5}{*}{ Interest in myself } & \multirow[t]{5}{*}{-} & \multirow[t]{5}{*}{-} \\
\hline & (ii) & 0.77 & & & \\
\hline & (iii) & 0.70 & & & \\
\hline & (iv) & 0.69 & & & \\
\hline & (v) & 0.59 & & & \\
\hline \multirow[t]{5}{*}{ (4) Disaster prevention } & (i) & 0.76 & \multirow{5}{*}{$\begin{array}{l}\text { Disaster prevention through } \\
\text { public and mutual assistances }\end{array}$} & 0.92 & \multirow{5}{*}{$\begin{array}{l}\text { Disaster prevention } \\
\text { through self-assistance }\end{array}$} \\
\hline & (ii) & 0.73 & & 0.44 & \\
\hline & (iii) & 0.70 & & 0.054 & \\
\hline & (iv) & 0.69 & & -0.0083 & \\
\hline & (v) & -0.23 & & -0.17 & \\
\hline \multirow[t]{5}{*}{ (5) Forest } & (i) & 0.76 & \multirow[t]{5}{*}{ Interest in forest } & \multirow[t]{5}{*}{-} & \multirow[t]{5}{*}{-} \\
\hline & (ii) & 0.76 & & & \\
\hline & (iii) & 0.75 & & & \\
\hline & (iv) & 0.74 & & & \\
\hline & (v) & 0.24 & & & \\
\hline \multirow[t]{5}{*}{ (6) Mt. Rokko } & (i) & 0.84 & \multirow[t]{5}{*}{ Interest in Mt. Rokko } & \multirow[t]{5}{*}{-} & \multirow[t]{5}{*}{-} \\
\hline & (ii) & 0.82 & & & \\
\hline & (iii) & 0.82 & & & \\
\hline & (iv) & 0.68 & & & \\
\hline & (v) & 0.55 & & & \\
\hline
\end{tabular}

prevention in cooperation with local municipalities, volunteers, community residents, and their family, while the latter component indicates that respondents consider it appropriate to conduct disaster prevention as individuals.

Considering the responses to questions regarding contributions, Table 8 shows that the majority of respondents answered 'Yes' to the first and second question. Similarly, the majority of respondents who answered 'No' to the first question also answered 'No' to the second question. These results imply that the respondents who were willing to pay the contributions and those who were not did not change their minds, even if the contribution amounts were varied. Cross-tabulation was conducted to review the relationship between respondents who answered 'Yes' to both the first and second questions, and age group. The results revealed that respondents who were older than 60 accounted for $39.0 \%$, while the same answers accounted for less than $10 \%$ in other age groups. On the other hand, looking at the same cross-tabulation between respondents who answered 'No' to both the first and second questions and age group, the percentage of respondents in the over 60 age group decreased to $31.2 \%$, while in other age groups, those between $40-44$ years and 50-54 years exceeded $10 \%$.

\section{WTP for forest maintenance}

Figure 4 shows the WTP forest maintenance contributions. The results show that the estimated WTP quantum median was 237 JPY (2.1 USD), with a mean of 210 JPY (1.9 USD). In considering the impact of the WTP, the former estimated cost applied to a public bathing facility was used, which operates near Mt. Rokko for 358 days a year, with 7 days set aside as non-business days for the maintenance of bath equipment. The daily cost of woodchips will be 10,150 JPY 


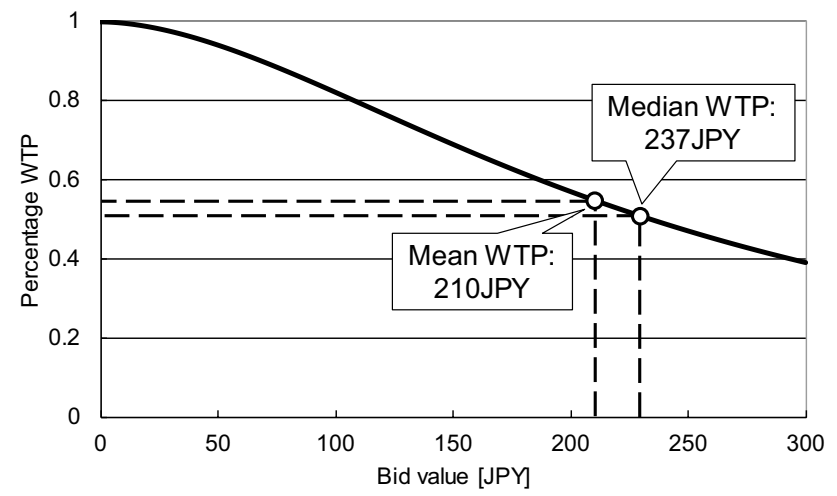

Fig. 4 WTP contributions ( 1 USD $=0.0090$ JPY $)$

(92 USD), based on the annual cost estimated in Sect. 3.1. In the case of collecting WTP contributions to cover the daily costs, at least 43 facility users per day would be the breakeven point. In fact, this calculation is based on the assumption that the business account balance includes not only woodchip procurement but also the operation of the facility, employment, etc. Although more detailed cost evaluation will be required, these results showed that the contributions would provide useful support for the business.

A multivariate analysis was also conducted to identify the variables that affected WTP. The results show that 'Interest in Mt. Rokko' and 'Frequency of visit to Mt. Rokko' were significant for $p$ values of $1 \%$ and $5 \%$, respectively. The influence of these two variables that became significant for WTP was at 0.11 JPY (0.0010 USD) for both. 'Interest in environment' was not significant, and these results imply that respondents who are specifically interested in Mt. Rokko have greater WTP than those who are concerned about the environment in general. People have many different environmental interests such as climate change, air and soil pollution, waste and wastewater, biodiversity, etc., and even those who are concerned about the environment will not necessarily be interested in forest maintenance on Mt. Rokko. The analysis also implied that 'Disaster prevention through self-assistance' was a factor that reduced the WTP, although in this instance, the $p$ value was not significant.

\section{Respondents' awareness and acceptable contribution amount}

Figure 5 shows the result of the path analysis of the acceptable amount of contribution. The analysis was conducted by assuming that demographics and synthesized variables on awareness could affect the level of contributions. In this figure, the arrows (passes), which became significant at the $5 \%$ level and $0.1 \%$ level, are represented by asterisks. The more negative the correlation coefficient of the path, the more positive the relationship between the variables. The results indicate that 'Interest in region' has a positive influence on the acceptable contribution amount, and, in turn, the 'Presence of children' highly influenced the 'Interest in region'. Respondents who supported higher contributions were strongly influenced by the 'Interest in environment', 'Interest in forest', and 'Interest in Mt. Rokko', respectively. On the other hand, there was no significant relationship between 'Residence years' and 'Interest in myself'. The analysis also revealed that support for 'Disaster prevention through self-assistance' was associated with support for lowering the contribution amount.

Kawamoto and Kim [50] surveyed the role of social capital in disaster waste management for residents affected by the 2011 Great East Japan Earthquake. Among their results was that citizens who relied on public or cooperative assistance implemented cooperative removal and disposal programs for waste generated by the disaster, while the group relying only on self-help was uncooperative. Our findings indicate that this group was not only uncooperative with regard to disaster relief but also had the same approach with regard to forest maintenance.
Fig. 5 Path analysis of the acceptable contribution amount. Note that $e$ indicates a latent variable, the value next to the arrow (path) indicates correlation coefficient and the value given in the upper right of the box indicates the coefficient of determination

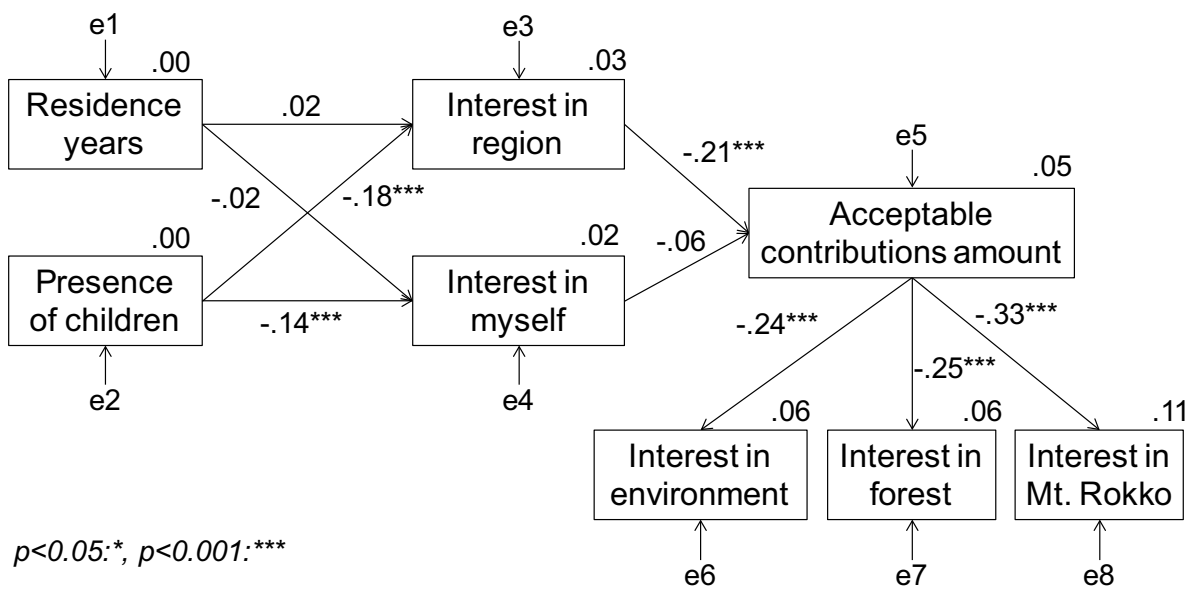




\section{Conclusions}

This study was conducted to clarify the environmental and economic aspects as well as social acceptability of establishing a bathing business that uses woody biomass to produce heat to contribute to regional revitalization. To achieve this aim, the annual energy potential, associated $\mathrm{CO}_{2}$ reduction, and costs were estimated for a case study in Mt. Rokko, Kobe, Japan. A questionnaire survey was conducted among Kobe residents to determine the social acceptance of the project, and the results were analysed using PCA, CVM, and path analysis.

The following conclusions can be drawn from our study:

1. The potential annual lumber and energy production were estimated as 2,130 $\mathrm{t}$ and 40,500 GJ, respectively, assuming that plantations at Mt. Rokko were thinned, and the thinned lumber were then transported and chipped. The annual cost of woodchip production was estimated as $630,000 \mathrm{JPY}(32,800 \mathrm{USD})$. The annual $\mathrm{CO}_{2}$ reduction by substituting fossil fuels for electricity production was $2,230 \mathrm{t}-\mathrm{CO}_{2}$; alternatively, the annual $\mathrm{CO}_{2}$ reduction achieved in the case of substituting bunker $\mathrm{A}$ or light oil used for heat production was estimated as 2,530 $\mathrm{t}-\mathrm{CO}_{2}$ or $2,450 \mathrm{t}-\mathrm{CO}_{2}$, respectively.

2. The analysis of survey results using PCA showed that only the first main component occurred in the five categories (Environment, Region, Myself, Forest, and Mt. Rokko). One category, disaster prevention, occurred in both the first and second main components, 'Disaster prevention through public and mutual assistances' and 'Disaster prevention through self-assistance'.

3. The WTP for Mt. Rokko's forestry maintenance contributions, if the bathing business is created, had a median and mean of 237 JPY (2.1 USD) and 210 JPY (1.9 USD), respectively. Although such detailed cost evaluation is not usually necessary, it indicates that if there are least 43 people making daily use of the facility, the business will reach its break-even point. This result reveals that the contributions will provide useful support for this business in terms of covering the daily costs.

4. Path analysis was conducted on the assumption that the demographics and synthesized variables regarding awareness could influence the contribution amount. It was shown that 'Interest in region' had a positive influence on the contribution amount, and 'Presence of children' was, in turn, highly supportive of the 'Interest in region'. In addition, respondents who supported higher contributions were also significantly influenced by the 'Interest in environment', 'Interest in forest', and 'Interest in Mt. Rokko', respectively.
This study used a bathing facility as a hypothetical business owing to the high level of interest in such facilities among the Japanese. However, it is important to emphasise that as of July 2018, the proposals remain hypothetical and there are no plans for construction. The CVM results could change if the actual construction was scheduled or if the business was already in operation. Although we considered only heat utilization to evaluate the social acceptance of the bathing business, the creation of business opportunities combining heat and power supply initiatives is also important from environmental and economic perspectives. Mt. Rokko is a mountain familiar to local residents, and this study only involved locals. However, the mountain also attracts many tourists and it would be informative to consider what tourists think about using a bathing facility heated with woodchips from Mt. Rokko. Although there are limitations to be discussed, our results imply that woodchip procurement costs might be covered by contributions from bathing facility patrons. In addition, the respondents who were interested in Mt. Rokko were familiar with the concept of deriving heat energy from woody biomass. This indicates that local residents are interested in the idea of the use and maintenance of resources in Mt. Rokko, and believe in the importance of promoting the POPDVLE using regional resources.

When a local municipality promotes the utilization of energy from woody biomass as a way of implementing the POPDVLE, they are required to propose associated policies and measures that will improve the acceptance of the plan by local residents. This involves making an effort to help local residents understand the benefits of using woody biomass and to increase awareness about renewable energy. The Sustainable Development Goals (SDG), associated with becoming an environmentally, economically, and socially sustainable society, were set by the United Nations in 2015. The Prime Minister of Japan and his Cabinet [51] established the 'SDGs Action Plan 2018' and implementation guidelines for the SDGs and eight priorities for their achievement. One of the eight priorities is regional revitalization through the construction of sustainable cities, which is consistent with the idea of the POPDVLE. In other words, regional revitalization using renewable energy must comply with the SDGs. This indicates that it is not only necessary to contribute to climate change mitigation using renewable energy, but that this must involve the participation, culture, and education of residents as well. The essence of the POPDVLE using regional resources is supporting the empowerment of residents. On the other hand, the construction of sustainable cities has been progressing in many countries in recent years. In particular, the so-called infrastructure export, which involves the sale of sustainable city concepts overseas as a package, has been adopted as a national strategy [52]. For example, countries such as Japan, Singapore, South Korea, etc., are selling these to Asian countries. Infrastructure 
exports target regional revitalization through the creation of environmentally and economically friendly infrastructure and living areas. However, when we discuss revitalization from the viewpoint of the SDGs, it is important to discuss it by taking account not only of environmental and economic perspectives but also social perspectives.

The aging population could become a more serious issue in developed countries such as Japan and emerging Asian countries in the future. Thus, the concept of the POPDVLE, which aims to build a sustainable society, must also conform to the SDGs; this thinking might be effective not only in Japan but in many countries. Kobe is a populous city surrounded by nature like Mt. Rokko. Proposing a revitalization policy is advantageous within the strategy of infrastructure exports, as it would not only provide environmental and economic benefits, but also improve residents' satisfaction using regional resources such as the woody biomass used in this study.

Acknowledgements This research was supported by the JSPS KAKENHI Grant Number JP16K12639, the Research on environmental economics and policy studies, Japan Ministry of Environment (Stage IV, No.7) and Graduate School of Human Development and Environment, Kobe University.

Open Access This article is distributed under the terms of the Creative Commons Attribution 4.0 International License (http://creativeco mmons.org/licenses/by/4.0/), which permits unrestricted use, distribution, and reproduction in any medium, provided you give appropriate credit to the original author(s) and the source, provide a link to the Creative Commons license, and indicate if changes were made.

\section{References}

1. International Energy Agency: Key word energy statistics 2017. International Energy Agency. https://www.iea.org/publications/ freepublications/publication/KeyWorld2017.pdf (2017) Accessed 19 Dec 2018

2. Japan Agency for Natural Resource and Energy: Basic energy plan 2018. Japan Ministry of Economy, Trade and Industry. http:// www.meti.go.jp/press/2018/07/20180703001/20180703001.html (2018). Accessed 19 Dec 2018 (in Japanese)

3. Chiavacci, D.: Inequality and the 2017 election: decreasing dominance of Abenomics and regional revitalization. In: Pekkanen, R.J., Reed, S.R., Scheiner, E., Smith, D.M. (eds.) Japan decides 2017: the Japanese General Election, pp. 219-242. Palgrave Macmillan, Gewerbestrasse (2018)

4. Japan Ministry of Environment: basic environment plan 2018. Japan Ministry of Environment. https://www.env.go.jp/press /105414.html (2018). Accessed 19 Dec 2018 (in Japanese)

5. Japan Forest Agency: Annual report on forest and forestry in Japan FY2016. Japan Forest Agency. http://www.rinya.maff.go.jp/j/ kikaku/hakusyo/28hakusyo/ (2017). Accessed 19 Dec 2018 (in Japanese)

6. Baran, B., Mehmet, S.M., Baris, B.A.: Utilization of energy from waste potential in Turkey as distributed secondary renewable energy source. Renew. Energy 90, 493-500 (2016). https://doi. org/10.1016/j.renene.2015.12.070
7. Ferreira, L.F.A., Otto, R.B., Silva, F.P., De Souza, S.N.M., De Souza, S.S., Ando Jr., O.H.: Review of the energy potential of the residual biomass for the distributed generation in Brazil. Renew. Sust. Energy Rev. 94, 440-455 (2018). https://doi.org/10.1016/j. rser.2018.06.034

8. Tabata, T.: Environmental impacts of utilizing woody biomass for energy. In: Bhaskar, A.T., Pandey, S.V., Mohan, D.J., Lee, S., Khanal, K. (eds.) Waste biorefinery, 1st edn, pp. 751-778. Elsevier, Cambridge (2018)

9. Rydén, L.: Is local energy supply a main road to sustainability? In: Leal, F.W., Úbelis, A., Bērziņa, D. (eds.) Sustainable development, knowledge society and smart future manufacturing technologies, pp. 19-31. Springer, Cham (2015)

10. Nishiguchi, S., Tabata, T.: Assessment of social, economic and environmental aspects of woody biomass energy utilization: direct burning and wood pellets. Renew. Sust. Energy Rev. 57, 1279-1286 (2016). https://doi.org/10.1016/j.rser.2015.12.213

11. Bulavskaya, T., Reynès, F.: Job creation and economic impact of renewable energy in the Netherlands. Renew. Energy 119, 528-538 (2018). https://doi.org/10.1016/j.renene.2017.09.039

12. la Rúa, C., Lechón, Y.: An integrated multi-regional inputoutput (MRIO) analysis of miscanthus biomass production in France: socio-economic and climate change consequences. Biomass BioEnergy 94, 21-30 (2016). https://doi.org/10.1016/j. biombioe.2016.08.003

13. Lăzăroiu, G., Traistă, E., Bădulescu, C., Orban, M., Pleşea, V.: Sustainable combined utilization of forest resources and coal in Romania. Environ. Eng. Manag. J. 7, 227-232 (2008). https:// doi.org/10.30638/eemj.2008.039

14. Ciupăgeanu, D.A., Lăzăroiu, G., Tîrşu, M.: Carbon dioxide emissions reduction by renewable energy employment in Romania. Proc 2017 Int. Conf. Elmch Power Systems. https://doi. org/10.1109/sielmen.2017.8123333

15. Kollmann, R., Neugebauer, G., Kretschmer, F., Truger, B., Kindermann, H., Stoeglehner, G., Ertl, T., Narodoslawsky, M.: Renewable energy from wastewater-practical aspects of integrating a wastewater treatment plant into local energy supply concepts. J. Clean. Prod. 155, 119-129 (2017). https://doi. org/10.1016/j.jclepro.2016.08.168

16. Šahović, N., Silva da, P.P.: Community renewable energyresearch perspectives. Energy Procedia. 106, 46-58 (2016). https://doi.org/10.1016/j.egypro.2016.12.104

17. Tabata, T., Tsai, P.: Heat Supply from municipal solid waste incineration plants in Japan: current situation and future challenges. Waste Manag. Res. 34, 148-155 (2016). https://doi. org/10.1177/0734242X15617009

18. Möller, B., Wiechers, E., Persson, U., Grundahl, L., Connolly, D.: Heat roadmap Europe: identifying local heat demand and supply areas with a European thermal atlas. Energy. 158, 281292 (2018). https://doi.org/10.1016/j.energy.2018.06.025

19. Ramachandra, T.V., Shruthi, B.V.: Spatial mapping of renewable energy potential. Renew. Sust. Energy Rev. 11, 1460-1480 (2007). https://doi.org/10.1016/j.rser.2005.12.002

20. Lourinho, G., Brito, P.: Assessment of biomass energy potential in a region of Portugal (Alto Alentejo). Energy. 81, 189-201 (2015). https://doi.org/10.1016/j.energy.2014.12.021

21. Baul, T.K., Datta, D., Alam, A.: A comparative study on household level energy consumption and related emissions from renewable (biomass) and non-renewable energy sources in Bangladesh. Energy Policy. 114, 598-608 (2018). https://doi. org/10.1016/j.enpol.2017.12.037

22. Kishita, Y., Nakatsuka, N., Akamatsu, F.: Scenario analysis for sustainable woody biomass energy businesses: the case study of a Japanese rural community. J. Clean Prod. 142, 1471-1485 (2017). https://doi.org/10.1016/j.jclepro.2016.11.161 
23. Stigka, E.K., Paravantis, J.A., Mihalakakou, G.K.: Social acceptance of renewable energy sources: a review of contingent valuation applications. Renew. Sust. Energy Rev. 32, 100-106 (2014). https://doi.org/10.1016/j.rser.2013.12.026

24. Paravantis, J.A., Stigka, E., Mihalakakou, G., Michalena, E., Hills, J.M., Dourmas, V.: Social acceptance of renewable energy projects: a contingent valuation investigation in Western Greece. Renew. Energy 123, 639-651 (2018). https://doi.org/10.1016/j. renene.2018.02.068

25. Belaïd, F.: Untangling the complexity of the direct and indirect determinants of the residential energy consumption in France. Energy Policy 110, 246-256 (2017). https://doi.org/10.1016/j. enpol.2017.08.027

26. Osiolo, H.H.: Willingness to pay for improved energy: evidence from Kenya. Renew. Energy 112, 104-112 (2017). https://doi. org/10.1016/j.renene.2017.05.004

27. Polis, H.J., Dreyer, S.J., Jenkins, L.D.: Public willingness to pay and policy preferences for tidal energy research and development: a study of households in Washington State. Ecol. Econ. 136, 213225 (2017). https://doi.org/10.1016/j.ecolecon.2017.01.024

28. Abdullah, S., Jeanty, P.W.: Willingness to pay for renewable energy: evidence from a contingent valuation survey in Kenya. Renew. Sust. Energy Rev. 15, 2974-2983 (2011). https://doi. org/10.1016/j.rser.2011.03.016

29. Hyogo Prefectural government: relevant documents for aged person, health and welfare. Hyogo Prefectural government. https ://web.pref.hyogo.lg.jp/hw07/hw07_000000012.html (2016). Accessed 19 Dec 2018 (in Japanese)

30. Japan Cabinet Office: 2015 Annual report on the aging society. Japan Cabinet Office. http://www8.cao.go.jp/kourei/whitepaper/ index-w.html (2015). Accessed 19 Dec 2018 (in Japanese)

31. National Institute of Population and Social Security Research: Household projections by Prefecture in Japan: 2010-2035. National Institute of Population and Social Security Research. http://www.ipss.go.jp/pp-ajsetai/e/hhprjpref2014/t-page_e.asp (2014) Accessed 19 Dec 2018

32. Kobe city government: Strategy for Mt. Rokko's forest management. Kobe city government. http://www.city.kobe.lg.jp.cache .yimg.jp/life/town/flower/rokkou/siryou1.pdf (2012). Accessed 19 Dec 2018 (in Japanese)

33. Kobe city government: 2014 Survey on number of visitors and trends in Kobe. Kobe city government. http://www.city.kobe.lg.jp/ information/data/statistics/sightseeing/h26sightseeing.pdf (2015). Accessed 19 Dec 2018 (in Japanese)

34. Japan Ministry of Land, Infrastructure, Transport and Tourism: National land numerical information database. Japan Ministry of Land, Infrastructure, Transport and Tourism. http://nlftp.mlit. go.jp/ksj/ (2018). Accessed 19 Dec 2018 (in Japanese)

35. Japan Ministry of Environment: Survey on vegetation in Japan. Japan Ministry of Environment. http://www.biodic.go.jp/kiso/vg/ vg_kiso.html (2018). Accessed 19 Dec 2018 (in Japanese)

36. Tabata, T., Torikai, H., Tsurumaki, M., Genchi, Y., Ukegawa, K.: Life cycle assessment for co-firing semi-carbonized fuel manufactured using woody biomass with coal: a case study in the central area of Wakayama. Jpn. Renew. Sust. Energy Rev. 15, 2772-2778 (2011). https://doi.org/10.1016/j.rser.2011.02.042

37. Japan Forest Agency. Construction and maintenance of road network for forest thinning in mountainous area. Japan Forest Agency. http://www.rinya.maff.go.jp/j/rinsei/singikai/pdf/15093 013.pdf (2015). Accessed 19 Dec 2018 (in Japanese)
38. Kansai Electric Power Company inc.: $2017 \mathrm{CO}_{2}$ intensity data. Kansai Electric Power Company inc. http://www.kepco.co.jp/ sustainability/kankyou/co2/ (2017). Accessed 19 Dec 2018 (in Japanese)

39. E-Gov: Ordinance for calculation of a greenhouse gas by the emissions of that substance produced in conjunction with the business activities of specified emitters. Ministry of Internal Affairs and Communications. http://elaws.e-gov.go.jp/search/elawsSearch/ elaws_search/lsg0500/detail?lawId=418M60001400003 (2016). Accessed 19 Dec 2018 (in Japanese)

40. Tabata, T., Okuda, T.: Life cycle assessment of woody biomass energy utilization: case study in Gifu Prefecture. Jpn. Energy 45, 944-951 (2012). https://doi.org/10.1016/j.energy.2012.06.064

41. Westrom, M.: Bathing in Japan: applying a practice theory vocabulary to energy use through ethnography. Energy Res. Soc. Sci. 44, 232-241 (2018). https://doi.org/10.1016/j.erss.2018.05.018

42. Encyclopædia Britannica Inc.: Furo-Japanese bath. Encyclopædia Britannica Online. https://www.britannica.com/technology/furoJapanese-bath (2018) Accessed 19 Dec 2018

43. Japan Ministry of Health, Labour and Welfare: 2016 Report on public health administration and service. Japan Ministry of Health, Labour and Welfare. http://www.mhlw.go.jp/toukei/ saikin/hw/eisei_houkoku/16/ (2017). Accessed 19 Dec 2018 (in Japanese)

44. Japan Productivity Center: White paper on leisure 2017. Japan Productivity Center. https://activity.jpc-net.jp/detail/srv/activity00 1513.html (2017). Accessed 19 Dec 2018 (in Japanese)

45. Walker, J.R.: Introduction to hospitality. Prentice Hall, New Jersey (1995)

46. Bartholomew, D.J.: Principal components analysis. In: Peterson, P., Tierney, R., Baker, E., McGaw, B. (eds.) International encyclopedia of education, 3rd edn, pp. 374-377. Elsevier Science, New York (2010)

47. Ahmed, S.U., Gotoh, K.: Cost-benefit analysis of environmental goods by applying the contingent valuation method. Springer, Tokyo (2006)

48. Kuriyama, K.: CVM for Excel Ver.3.2. Graduate School of Agriculture, Kyoto University. http://kkuri.eco.coocan.jp/research/ workingpaper/WP1101CVM32.pdf (2011). Accessed 19 Dec 2018 (in Japanese)

49. Lee, S.Y., Song, X.Y.: Structural equation models. In: Peterson, P., Tierney, R., Baker, E., McGaw, B. (eds.) International encyclopedia of education, 3rd edn, pp. 453-458. Elsevier Science, New York (2010)

50. Kawamoto, K., Kim, K.: Social capital and efficiency of earthquake waste management in Japan. Int. J. Disaster Risk Reduct. 18, 256-266 (2016). https://doi.org/10.1016/j.ijdrr.2015.10.003

51. Prime Minister of Japan and His Cabinet: SDGs action plan 2018, https://www.kantei.go.jp/jp/singi/sdgs/pdf/actionplan2018.pdf (2017). Accessed 19 Dec 2018 (in Japanese)

52. Japan Business Federation: Towards strategic promotion of the infrastructure export. Japan Business Federation. http://www. keidanren.or.jp/en/policy/2015/105.html (2015). Accessed 19 Dec 2018 (in Japanese)

Publisher's Note Springer Nature remains neutral with regard to jurisdictional claims in published maps and institutional affiliations. 